\title{
Faktor-Faktor yang Berhubungan dengan Hipertensi Pada Lansia di Atas Umur 65 Tahun
}

\author{
Factors Related with Hypertension on The Elderly over 65 Years
}

\author{
Sri Agustina, Siska Mayang Sari, Reni Savita
}

\section{Program Studi Ilmu Keperawatan STIKes Hang Tuah Pekanbaru}

\begin{abstract}
ABSTRAK
Proses menua merupakan proses yang alamiah dimana terjadi berbagai perubahan pada seluruh sistem tubuh lansia, termasuk sistem kardiovaskuler yang biasanya diikuti oleh penyakit utama yakni hipertensi. Penelitian ini bertujuan untuk mengetahui faktor-faktor yang berhubungan dengan hipertensi pada lansia diatas Umur 65 tahun. Pengambilan data dilakukan pada 87 orang responden yang merupakan lansia di atas umur 65 tahun secara total sampling, dengan alternatif uji Fisher pada faktor keturunan dan obesitas. Hasil uji menunjukkan adanya hubungan antara faktor keturunan dengan hipertensi Pvalue $\leq$ 0,05 , tidak ada hubungan antara faktor jenis kelamin, obesitas, kebiasaan merokok, stres, olahraga dengan Pvalue $>0,05$. Disarankan kepada lansia diatas 65 tahun yang menderita hipertensi untuk melakukan pengontrolan tekanan darah secara rutin dan disarankan kepada petugas kesehatan untuk melakukan promosi kesehatan atau pencegahan hipertensi terkait lansia.
\end{abstract}

Kata kunci : Faktor-faktor, Hipertensi, Lansia.

\section{ABSTRACT}

Aging process was an natural process which occured any changes at all body system of elderly, included cardiovascular system in which followed by main deseases were hypertension. The aim of this research was determined the factors related with hypertension on the elderly over 65 years. The data was collected on 87 elderly over 65 years old with hypertension whithin total sampling and also Fisher test as alternative test in factor heredity and obesity. The result showed there were relationship between heredity and hypertension with $p$ value $\leq$ 0,05. There was no relationship between gender, obesity, smoking, stress, sport and hypertension with $p$ value $>$ 0,05. Recomended to elderly over 65 years old with hypertension to did routine blood pressure control and health officer should to promote health education about prevention of hypertension in elderly.

Keywords : Elderly, Factors, Hypertension.

\section{PENDAHULUAN}

Pembangunan kesehatan di Indonesia merupakan upaya kesehatan untuk mencapai kemampuan hidup sehat bagi setiap penduduk dalam mewujudkan derajat kesehatan yang optimal. Keberhasilan pemerintah dalam pembangunan nasional, telah terwujud hasil yang positif diberbagai bidang, yaitu adanya kemajuan ekonomi, perbaikan lingkungan hidup, kemajuan ilmu pengetahuan dan teknologi, terutama dibidang medis sehingga dapat meningkatkan kualitas kesehatan penduduk serta meningkatkan Usia Harapan Hidup (UHH). Akibatnya jumlah penduduk yang berusia lanjut cenderung meningkat dan bertambah lebih cepat (Depkes RI, 2006).

Salah satu hasil pembangunan kesehatan di Indonesia adalah meningkatnya angka harapan hidup(life expectancy). Semakin meningkatnya UHH penduduk, menyebabkan jumlah penduduk lansia terus meningkat dari tahun ke tahun. Peningkatan UHH dari 45 tahun di awal tahun 1950 menjadi 65 tahun pada saat ini (Fatmah, 2010). Hal ini berarti kelompok resiko dalam masyarakat kita menjadi lebih tinggi. Meningkatnya populasi lansia ini bukan hanya fenomena di Indonesia saja tetapi juga secara global (Notoatmodjo, 2007).

Penduduk lansia di Indonesia pada tahun 1980 hanya 7,9 juta orang $(5,45 \%)$ dari jumlah penduduk di Indonesia dengan UHH 52,2 tahun. Pada tahun 1990 terjadi peningkatan lansia mencapai angka 11,3 juta $(6,29 \%)$ dari jumlah penduduk di Indonesia dengan UHH 59,8 tahun. Pada tahun tahun 2000 jumlah ini meningkat menjadi 14,4 juta orang $(7,18 \%)$ dari jumlah penduduk di Indonesia dengan UHH 67,4 tahun. Pada tahun 2006 angka meningkat hingga dua kali lipat menjadi 19 juta orang $(8,9 \%)$ dari jumlah penduduk di Indonesia dengan UHH 66,2 tahun dan diperkirakan tahun 2020 mencapai 28,8 juta orang $(11,34 \%)$ dari jumlah penduduk di Indonesia dengan UHH 71,1 tahun (Efendi \& Makhfudli, 2009).

Peningkatan jumlah lansia di Indonesia ini memberikan suatu perhatian khusus pada lansia yang mengalami suatu proses menua. Permasalahan- 
permasalahan yang perlu perhatian khusus untuk lansia berkaitan dengan berlangsungnya proses menjadi tua, yang berakibat timbulnya perubahan fisik, kognitif, perasaan, sosial, dan seksual. (Azizah, 2011).

Perubahan-perubahan pada lansia di negaranegara maju yaitu perubahan pada sistem kardiovaskuler yang merupakan penyakit utama yang memakan korban karena akan berdampak pada penyakit lain seperti hipertensi, penyakit jantung koroner, jantung pulmonik, kardiomiopati, stroke, gagal ginjal (Fatmah, 2010).

Hipertensi atau tekanan darah tinggi merupakan sebuah kondisi medis dimana orang yang tekanan darahnya meningkat diatas normal yaitu 140/90 $\mathrm{mmHg}$ dan dapat mengalami resiko kesakitan (morbiditas) bahkan kematian (mortalitas). Penyakit ini sering dikatakan sebagai the silent diseases. Faktor resiko hipertensi dibagi menjadi 2 golongan yaitu hipertensi yang tidak bisa diubah dan hipertensi yang dapat diubah. Hipertensi yang dapat diubah meliputi merokok, obesitas, gaya hidup yang monoton dan stres. Hipertensi yang tidak dapat dirubah meliputi usia, jenis kelamin, suku bangsa, faktor keturunan (Rusdi \& Isnawati, 2009).

Hipertensi pada lansia di Amerika mempunyai prevalensi yang tinggi pada usia 65 tahun didapatkan $60-80 \%$ atau sekitar lima puluh juta warga lansia Amerika mempunyai prevalensi tinggi untuk hipertensi (Yenni, 2011). Menurut Depkes (2006) pada golongan umur 55-64 tahun, penderita hipertensi pada pria dan wanita sama banyak. Dari beberapa penelitian tingginya prevalensi hipertensi sejalan dengan bertambahnya umur. Berdasarkan penelitian yang dilakukan di 6 kota besar seperti Jakarta, Padang, Bandung, Yogyakarta, Denpasar, dan Makasar terhadap usia lanjut (55-85), didapatkan prevalensi hipertensi sebesar 52,5\% (Sarasaty, 2011).

Berdasarkan data dari Dinas Kesehatan Kota Pekanbaru pada tahun 2011 diperoleh bahwa penderita hipertensi lansia diatas umur 65 tahun tertinggi berada di puskesmas Simpang Tiga. Puskesmas Simpang Tiga merupakan puskesmas yang berada di kecamatan Bukit Raya yang terdiri dari kelurahan Simpang Tiga dan mempunyai tiga posbindu lansia. Setelah di observasi data yang diperoleh dari puskesmas Simpang Tiga jumlah lansia yang menderita hipertensi diatas 65 tahun sebanyak 89 orang. Hasil wawancara terhadap petugas kesehatan diperoleh informasi bahwa penderita hipertensi pada lansia jarang melakukan pengontrolan dan pengecekan tekanan darah secara rutin.

Dari hasil wawancara awal didapatkan 5 dari 7 lansia berumur diatas 65 tahun yang menderita hipertensi mempunyai kebiasaan merokok mengkonsumsi kopi, suka makan yang asin-asin, dan jarang berolah raga.
Melihat fenomena tersebut di atas, maka sangatlah penting bagi lansia untuk melakukan pengontrolan tekanan darah secara rutin. Mengingat penting hal tersebut, penulis tertarik untuk melakukan penelitian terhadap "faktor-faktor yang berhubungan dengan hipertensi pada lansia di atas umur 65". Penelitian ini bertujuan untuk mengetahui faktorfaktor yang berhubungan dengan hipertensi pada lansia diatas umur 65 tahun.

\section{METODOLOGI}

Jenis penelitian ini adalah penelitian kuantitatif dengan rancangan cross sectional study. Adapun yang diamati meliputi faktor-faktor yang berhubungan dengan hipertensi pada lansia di atas umur 65. Semua faktor diukur secara bersamaan dalam satu waktu. Penelitian ini dilaksanakan di puskesmas Simpang Tiga. Berdasarkan data dari Dinas Kesehatan Kota tahun 2011 diperoleh bahwa hipertensi pada lansia tertinggi terdapat pada wilayah kerja puskesmas Simpang Tiga Pekanbaru.

Populasi pada penelitian ini adalah seluruh lansia yang berobat diatas umur 65 tahun di puskesmas Simpang Tiga yang berjumlah 87 orang. Sampel dalam penelitian ini berjumlah 87 orang lansia yang menderita hipertensi yang berobat di puskesmas Simpang Tiga Pekanbaru. Teknik sampling yang digunakan adalah total sampling dengan cara pengambilan sampel dengan mengambil semua anggota populasi menjadi sampel. Dengan kriteria inklusi yaitu ; Lansia berusia diatas 65 tahun dengan hipertensi yang berobat di puskesmas Simpang Tiga Pekanbaru, dapat berkomunikasi dengan baik dan bersedia menjadi responden sedangkan kriteria eksklusi yaitu; Terdapat keadaan gangguan jiwa seperti demensia, pikun dan subjek meninggal dunia atau tidak ditemukan.

Pengumpulan data dilakukan dengan cara yaitu; Pengukuran tekanan darah (sistolik dan diastolik) dengan menggunakan alat Sphygmomanometer air raksa dan auskultasi arteri dengan menggunakan stetoskop. Pengumpulan data obesitas peneliti mengumpulkan data dengan menggunakan cara ukur Indeks Massa Tubuh. Pengumpulan data faktor jenis kelamin, keturunan, kebiasaan merokok, stres, dan olahraga yang mempengaruhi hipertensi peneliti melakukan pengukuran secara langsung dengan menggunakan kuesioner kepada responden yang berisi pertanyaan dan pengumpulan data stress yang menggunakan Depression anxiety stress scales (DASS). Penyusunan untuk mengukur skala stres pada lansia terdiri dari 25 pertanyaan yang telah dimodifikasi. Kuesioner stres dilakukan uji normalitas dan menghitung rata-rata mean yang artinya apabila lansia mengalami stres diatas nilai rata-rata $(29,8046)$. 
Analisa data yang dilakukan yaitu analisa univariat untuk menggambarkan distribusi frekuensi dari variabel independen (jenis kelamin, keturunan, obesitas, kebiasaan merokok, stres, olahraga) maupun variabel dependen (hipertensi). Analisa bivariat dilakukan dengan menggunakan uji Chi Square, dengan derajat kepercayaan 95\%.

\section{HASIL}

\section{Analisis Univariat}

Lansia yang berumur 60-74 tahun yakni sebanyak 73 orang $(83,9 \%)$ dan sebanyak 40 orang $(46,0 \%)$ berasal dari suku melayu (Tabel 1). Sebagian besar lansia berada pada kondisi hipertensi ringan yakni sebanyak 61 orang $(70,1 \%)$ (Tabel 2$)$. Sebagian lansia berjenis kelamin laki-laki yakni sebanyak 45 orang $(51,7 \%)$. Pada umumnya lansia yang mempunyai riwayat keturunan hipertensi sebanyak 79 orang $(90,8 \%)$, dan lansia yang tidak obesitas yakni sebanyak 74 orang $(85,1 \%)$. Disamping itu, juga diperoleh hasil bahwa sebagian besar lansia memiliki kebiasaan merokok sebanyak 49 orang $(56,3 \%)$, mengalami stres sebanyak 62 orang $(71,3 \%)$ dan tidak rutin berolahraga yakni sebanyak 57 orang $(65,5 \%)$ (Tabel 3).

Tabel 4.1

Distribusi Frekuensi Lansia di atas Umur 65 Tahun yang Berobat di puskesmas Simpang Tiga Pekanbaru Berdasarkan Karakteristik Umur dan Suku di puskesmas Simpang Tiga Pekanbaru $(\mathrm{N}=87)$

\begin{tabular}{clcc}
\hline No & Variabel & Jumlah & Persentase(\%) \\
\hline 1. & Umur & & \\
& $-60-74$ & 73 & 83,9 \\
& $-75-90$ & 14 & 16,1 \\
\hline 2. & Suku & & \\
& - Minang & 34 & 39,1 \\
& - Melayu & 40 & 46,0 \\
& - Jawa & 10 & 11,5 \\
& - Batak & 3 & 3,4 \\
\hline & Total & 87 & 100 \\
\hline
\end{tabular}

Tabel 4.2

Distribusi Frekuensi Hipertensi Lansia di atas 65 Tahun yang Berobat di puskesmas Simpang Tiga Pekanbaru

$(\mathbf{N}=\mathbf{8 7})$

\begin{tabular}{clcc}
\hline No & Hipertensi & Jumlah & Persentase \\
\hline 1 & Ringan & 61 & 70,1 \\
2 & Sedang & 26 & 29,9 \\
3 & Berat & 0 & 0 \\
4 & Sangat berat & 0 & 0 \\
& Total & $\mathbf{8 7}$ & $\mathbf{1 0 0}$ \\
\hline
\end{tabular}

Tabel 4.3

Distribusi Frekuensi Faktor-faktor yang Berhubungan dengan Hipertensi pada Lansia di atas Umur 65 Tahun yang Berobat di puskesmas Simpang Tiga Pekanbaru $(\mathrm{N}=\mathbf{8 7})$

\begin{tabular}{clcc}
\hline No & Faktor-faktor & Jumlah & Persentase \\
\hline 1 & Jenis kelamin & & \\
& - Laki-laki & 45 & 51,7 \\
& - Perempuan & 42 & 48,3 \\
\hline 2 & Keturunan & & \\
& - Ada & 79 & 90,8 \\
& - Tidak & 8 & 9,2 \\
\hline 3 & Obesitas & & \\
& - Obesitas & 13 & 14,9 \\
& - Tidak obesitas & 74 & 85,1 \\
\hline 4 & Kebiasaan merokok & & \\
& - Merokok & 49 & 56,3 \\
& - Tidak merokok & 38 & 43,7 \\
\hline 5 & Stres & & \\
& - Stres & 62 & 71,3 \\
& - Tidak stres & 25 & 28,7 \\
\hline 6 & Olahraga & & \\
& - Rutin & 30 & 34,5 \\
& - Tidak rutin & 57 & 65,5 \\
\hline & Total & 87 & 100 \\
\hline
\end{tabular}

\section{Analisis Bivariat}

Berdasarkan hasil penelitian dapat dilihat bahwa lansia yang memiliki hipertensi ringan pada jenis kelamin laki-laki sebanyak 33 orang $(73,3 \%)$, sementara itu lansia yang memiliki hipertensi ringan pada jenis kelamin perempuan sebanyak 28 orang $(66,7 \%)$. Berdasarkan uji statistik diperoleh nilai $\mathrm{p}=$ value $>0,05$ yakni, sebesar 0,497 . Hal ini berarti Ho gagal ditolak yaitu tidak ada hubungan antara jenis kelamin dengan hipertensi.

Dari hasil faktor keturunan yang diteliti dapat dilihat bahwa lansia yang memiliki hipertensi ringan mempunyai riwayat keturunan hipertensi sebanyak 59 orang $(74,7 \%)$, sementara itu lansia yang hipertensi ringan yang tidak mempunyai riwayat keturunan hipertensi sebanyak 2 orang $(25,0 \%)$. Berdasarkan uji statistik menggunakan alternatif uji Fisher diperoleh nilai $\mathrm{p}=$ value $<0,05$ yakni, sebesar 0,008 . Hal ini berarti Ho ditolak yaitu ada hubungan antara keturunan dengan hipertensi. Pada hasil analisia juga diperoleh nilai $\mathrm{OR}=8,850$, Artinya lansia dengan riwayat keturunan hipertensi mempunyai peluang 8,8 kali menderita hipertensi ringan dibandingkan dengan lansia yang tidak ada riwayat keturunan hipertensi.

Berdasarkan hasil penelitian pada faktor obesitas dapat dilihat bahwa lansia yang memiliki hipertensi ringan yang obesitas sebanyak 8 orang (61,5\%), sementara itu lansia yang hipertensi ringan yang tidak obesitas sebanyak 53 orang $(71,6 \%)$. Berdasarkan uji statistik menggunakan alternatif uji Fisher diperoleh nilai $\mathrm{p}=$ value $>0,05$ yakni, sebesar 
0,518. Hal ini berarti Ho gagal ditolak yaitu tidak ada hubungan antara obesitas dengan hipertensi.

Berdasarkan hasil penelitian pada faktor kebiasaan merokok dapat dilihat bahwa lansia yang memiliki hipertensi ringan dengan kebiasaan merokok sebanyak 33 orang $(67,3 \%)$ sementara itu lansia yang tidak merokok sebanyak $28(73,3 \%)$. Berdasarkan uji statistik diperoleh nilai $\mathrm{p}=$ value $>0,05$ yakni, sebesar 0,522 . Hal ini berarti Ho gagal ditolak yaitu tidak ada hubungan antara kebiasaan merokok dengan hipertensi.

Berdasarkan hasil penelitian pada faktor stres dapat dilihat bahwa lansia yang memiliki hipertensi ringan yang mengalami stres sebanyak 44 orang $(71,0 \%)$, sementara itu lansia yang hipertensi ringan yang tidak mengalami stres sebanyak 17 orang $(68,0 \%)$. Berdasarkan uji statistik diperoleh nilai $\mathrm{p}=$ value $>0,05$ yakni, sebesar 0,784 . Hal ini Ho gagal ditolak yaitu tidak ada hubungan antara stres dengan hipertensi.

Berdasarkan hasil penelitian pada faktor olahraga dapat dilihat bahwa lansia yang memiliki hipertensi ringan dengan rutin berolahraga sebanyak 18 orang $(60,0 \%)$ sementara itu lansia yang hipertensi ringan dengan tidak rutin berolahraga sebanyak 43 orang (75,4\%). Berdasarkan uji statistik diperoleh nilai $p=$ value $>0,05$ yakni, sebesar 0,135 . Hal ini berarti Ho gagal ditolak yaitu tidak ada hubungan antara olahraga dengan hipertensi.

Tabel 4.4

Uji Dependensi Faktor-faktor yang Berhubungan dengan Hipertensi pada Lansia di atas Umur 65 Tahun yang Berobat di puskesmas Simpang Tiga Pekanbaru Tahun 2013 (N=87)

\begin{tabular}{|c|c|c|c|c|c|c|c|c|c|}
\hline \multirow[t]{3}{*}{ No } & \multirow[t]{3}{*}{ Faktor-faktor } & \multicolumn{4}{|c|}{ Hipertensi } & \multicolumn{2}{|c|}{ Total } & \multirow[t]{3}{*}{ P Value } & \multirow{3}{*}{$\begin{array}{c}\text { OR } \\
(\mathrm{CI}=95 \%)\end{array}$} \\
\hline & & \multicolumn{2}{|c|}{ Ringan } & \multicolumn{2}{|c|}{ Sedang } & & & & \\
\hline & & $n$ & $\%$ & n & $\%$ & $\mathbf{N}$ & $\%$ & & \\
\hline 1. & \begin{tabular}{ll}
\multicolumn{2}{l}{ Jenis kelamin } \\
$-\quad$ Laki- laki \\
$-\quad$ Perempuan
\end{tabular} & $\begin{array}{l}33 \\
28\end{array}$ & $\begin{array}{l}73,3 \\
66,7\end{array}$ & $\begin{array}{l}12 \\
14\end{array}$ & $\begin{array}{l}26,7 \\
33,3\end{array}$ & $\begin{array}{l}45 \\
42\end{array}$ & $\begin{array}{l}100 \\
100\end{array}$ & 0,497 & $\begin{array}{c}1,375(0,547- \\
3,453)\end{array}$ \\
\hline 2. & $\begin{array}{l}\text { Keturunan } \\
\text { - } \quad \text { Ada } \\
\text { - } \quad \text { Tidak }\end{array}$ & $\begin{array}{c}59 \\
2\end{array}$ & $\begin{array}{l}74,7 \\
25,0\end{array}$ & $\begin{array}{c}20 \\
6\end{array}$ & $\begin{array}{l}25,3 \\
75,0\end{array}$ & $\begin{array}{c}79 \\
8\end{array}$ & $\begin{array}{l}100 \\
100\end{array}$ & $0,008 *$ & $\begin{array}{c}8,850(1,651- \\
47,425)\end{array}$ \\
\hline 3. & $\begin{array}{l}\text { Obesitas } \\
\text { - } \text { Obesitas } \\
\text { - } \quad \text { Tidak obesitas }\end{array}$ & $\begin{array}{c}8 \\
53\end{array}$ & $\begin{array}{l}61,5 \\
71,6\end{array}$ & $\begin{array}{c}5 \\
21\end{array}$ & $\begin{array}{l}38,5 \\
28,4\end{array}$ & $\begin{array}{l}13 \\
74\end{array}$ & $\begin{array}{l}100 \\
100\end{array}$ & 0,518 & $\begin{array}{c}0,634(0,186- \\
2,161)\end{array}$ \\
\hline 4. & $\begin{array}{l}\text { Kebiasaan merokok } \\
\text { - } \text { Merokok } \\
\text { - } \quad \text { Tidak merokok }\end{array}$ & $\begin{array}{l}33 \\
28\end{array}$ & $\begin{array}{l}67,3 \\
73,7\end{array}$ & $\begin{array}{l}16 \\
10\end{array}$ & $\begin{array}{l}32,7 \\
26,3\end{array}$ & $\begin{array}{l}49 \\
38\end{array}$ & $\begin{array}{l}100 \\
100\end{array}$ & 0,522 & $\begin{array}{c}0,737(0,289- \\
1,880)\end{array}$ \\
\hline 5. & $\begin{array}{l}\text { Stres } \\
-\quad \text { Stres } \\
-\quad \text { Tidak stres }\end{array}$ & $\begin{array}{l}44 \\
17\end{array}$ & $\begin{array}{l}71,0 \\
68,0\end{array}$ & $\begin{array}{c}18 \\
8\end{array}$ & $\begin{array}{l}29,0 \\
32,0\end{array}$ & $\begin{array}{l}62 \\
25\end{array}$ & $\begin{array}{l}100 \\
100\end{array}$ & 0,784 & $\begin{array}{c}1,150(0,422- \\
3,138)\end{array}$ \\
\hline 6. & \begin{tabular}{ll}
\multicolumn{2}{l}{ Olahraga } \\
$-\quad$ Rutin \\
$-\quad$ Tidak rutin
\end{tabular} & $\begin{array}{l}18 \\
43\end{array}$ & $\begin{array}{l}60,0 \\
75,4\end{array}$ & $\begin{array}{l}12 \\
14\end{array}$ & $\begin{array}{l}40,0 \\
24,6\end{array}$ & $\begin{array}{l}30 \\
57\end{array}$ & $\begin{array}{l}100 \\
100\end{array}$ & 0,135 & $\begin{array}{c}0,488(0,189- \\
1,259)\end{array}$ \\
\hline & Total & 61 & 70,1 & 26 & 29,9 & 87 & 100 & & \\
\hline
\end{tabular}

\section{PEMBAHASAN}

Gambaran hipertensi pada lansia di atas umur 65 tahun yang berobat di puskesmas Simpang Tiga Pekanbaru

Berdasarkan Tabel 4.2 dapat dilihat bahwa sebagian besar lansia menderita hipertensi ringan yaitu sebanyak 61 orang $(70,1 \%)$ dan lansia yang menderita hipertensi sedang sebanyak 26 orang $(29,9 \%)$. Hal ini dapat disimpulkan bahwa hipertensi merupakan masalah yang serius pada lansia di puskesmas Simpang Tiga dan perlu penanganan atau pencegahan berkaitan dengan hipertensi seperti melakukan pola hidup sehat agar tidak mengalami komplikasi lebih lanjut.

Hal ini didukung oleh teori Rusdi dan Isnawati (2009) yang menyatakan bahwa orang yang tekanan darahnya meningkat diatas normal yaitu $140 / 90 \mathrm{mmHg}$ dapat mengalami resiko kesakitan (morbiditas) bahkan kematian (mortalitas). 
Gambaran karakteristik umur pada lansia di atas umur 65 tahun yang berobat di puskesmas Simpang Tiga Pekanbaru

Berdasarkan tabel 4.1 dapat dilihat bahwa karakteristik umur lansia yang terkena hipertensi terjadi pada umur 60-74 tahun sebanyak 73 orang $(83,9 \%)$ dan pada umur $75-90$ tahun sebanyak 14 orang $(16,1 \%)$. Hasil penelitian ini sedikit berbeda dengan penelitian Lewa, Pramantara, Rahayujati (2010) menunjukkan bahwa umur lansia yang terkena hipertensi berada pada rentang umur 60-69 sebanyak 43 orang $(36,1)$ dan pada umur $\geq 70$ tahun sebanyak 76 orang $(63,9 \%)$.

Gambaran karakteristik suku pada lansia di atas 65 tahun yang berobat di puskesmas Simpang Tiga Pekanbaru.

Berdasarkan tabel 4.1 dapat dilihat bahwa karakteristik suku lansia yang terkena hipertensi terjadi pada lansia yang bersuku Melayu dengan jumlah sebanyak 40 orang $(46,0 \%)$. Selain itu jumlah lansia yang bersuku Minang yang menderita hipertensi sebanyak 34 orang $(39,1 \%)$ dan lansia yang berasal dari suku Jawa sebanyak 10 orang $(11,5 \%)$ sedangkan lansia yang bersuku Batak sebanyak 3 orang $(3,4 \%)$. Dari hasil wawancara peneliti pada 15 orang lansia, ternyata lansia yang berasal dari suku melayu suka mengkonsumsi makanan yang bersantan dan berlemak sehingga bisa memicu terjadinya hipertensi.

Hal ini sejalan dengan teori yang dinyatakan oleh Smeltzer dan Bare (2002) yakni suku atau budaya merupakan salah satu faktor resiko terjadinya hipertensi seperti mengkonsumsi makanan kegemaran.

Hubungan antara jenis kelamin dengan hipertensi pada lansia diatas 65 tahun yang berobat di puskesmas Simpang Tiga Pekanbaru.

Berdasarkan hasil uji statistik menunjukkan Ho gagal ditolak yaitu tidak terdapatnya hubungan bermakna antara jenis kelamin dengan hipertensi pada lansia dengan hasil $p=$ value $>0,05$, yakni sebesar 0,497 . Hasil penelitian ini sejalan dengan penelitian Rachman (2011) yaitu tidak terdapatnya hubungan yang bermakna antara jenis kelamin dengan hipertensi pada lansia. Hal tersebut kemungkinan disebabkan oleh telah menebalnya dinding arteri akibat menumpuknya zat kolagen pada lapisan otot selama bertahun-tahun, yang berdampak pada penyempitan dan pengerasan pembuluh darah sehingga jantung memompa darah lebih kuat dan menimbulkan hipertensi.

Hubungan antara keturunan dengan hipertensi pada lansia diatas 65 tahun yang berobat di puskesmas Simpang Tiga Pekanbaru.

Berdasarkan hasil uji statistik menunjukkan bahwa terdapat hubungan bermakna antara keturunan dengan hipertensi dengan $p=$ value $<0,05$, yakni sebesar 0,008. Dengan hasil analisis diperoleh pula nilai $\mathrm{OR}=8,850$, artinya lansia dengan riwayat keturunan hipertensi mempunyai peluang 8,8 kali menderita hipertensi ringan dibandingkan dengan yang tidak ada keturunan. Hasil penelitian ini sejalan dengan penelitian Rachman (2011) yaitu riwayat keluarga yang memiliki hipertensi merupakan faktor risiko terjadinya hipertensi. Hal ini didukung dengan teori yang dikemukakan oleh Smeltzer dan Bare (2002) yaitu faktor resiko hipertensi yang tidak dapat dirubah salah satunya adalah riwayat keluarga yang positif menderita masalah jantung atau kardiovaskuler.

Hubungan antara obesitas dengan hipertensi pada lansia diatas 65 tahun yang berobat di puskesmas Simpang Tiga Pekanbaru.

Berdasarkan uji statistik menggunakan alternatif uji Fisher diperoleh nilai $p=$ value $>0,05$, yakni sebesar 0,518 . Hal ini berarti $\mathrm{H} 0$ gagal ditolak yaitu tidak ada hubungan antara obesitas dengan hipertensi pada lansia diatas umur 65 tahun di puskesmas Simpang Tiga Pekanbaru. Tidak terdapatnya hubungan tersebut kemungkinan disebabkan oleh adanya faktor lain yang lebih berpengaruh terhadap hipertensi seperti keturunan, olahraga, stres, merokok, dan jenis kelamin. Hasil penelitian ini didukung dengan hasil penelitian Rachman (2011) yaitu tidak terdapatnya hubungan antara obesitas dengan hipertensi.

Hubungan antara kebiasaan merokok dengan hipertensi pada lansia diatas 65 tahun yang berobat di puskesmas Simpang Tiga Pekanbaru.

Berdasarkan uji statistik diperoleh nilai $p=$ value $>0,05$, yakni sebesar 0,522 . Hal ini berarti Ho gagal ditolak yaitu tidak ada hubungan antara kebiasaan merokok dengan hipertensi. Hasil penelitian ini sejalan dengan penelitian Rachman (2011) yang menunjukkan bahwa tidak ada hubungan bermakna antara kebiasaan merokok dengan hipertensi pada lansia. Namun, hasil kedua penelitian ini bertolak belakang dengan teori yang dikemukakan oleh Familia dan Dewi (2010) yang menyatakan bahwa salah satu faktor resiko dari hipertensi adalah kebiasaan merokok dan faktor resiko ini termasuk kedalam golongan faktor hipertensi yang bisa dirubah (modifiabel).

Kebiasaan merokok dapat menyebabkan gangguan kardiovaskuler pada lansia sebagaimana dengan teori yang dikemukakan oleh Ode (2012) yaitu penyebab terjadinya hipertensi adalah terdiri dari berbagai faktor seperti stres, kegemukan, merokok, hipernatriumia. 
Hubungan antara stres dengan hipertensi pada lansia diatas 65 tahun yang berobat di puskesmas Simpang Tiga Pekanbaru.

Berdasarkan hasil uji statistik diperoleh nilai $p$ $=$ value $>0,05$, yakni sebesar 0,784 . Hal ini berarti Ho gagal ditolak yaitu tidak ada hubungan antara stres dengan hipertensi. Hal tersebut dapat disebabkan karena ketika dilakukan pengumpulan data, lansia sedang tidak mengalami stres atau masalah tertentu yang dapat menimbulkan terjadinya stres berkepanjangan. Hasil penelitian ini bertolak belakang dengan penelitian Lewa, Pramantara, Rahayujati (2010) yang menunjukkan bahwa Ho ditolak yaitu ada hubungan yang bermakna antara stres dengan hipertensi pada lansia. Variabel stres pada lansia pada penelitian di puskesmas Simpang Tiga ini adalah dengan menggunakan analisa bivariat. Sementara itu, pada penelitian Lewa, Pramantara, Rahayujati (2010) analisa variabel stres dilakukan dengan cara multivariat. Hasil penelitian ini bertolak belakang dengan teori yang dikemukakan oleh Smeltzer dan Bare (2002) yaitu pasien yang stres atau cemas tidak akan mampu untuk beristirahat dengan cukup. Stres emosional mengakibatkan vasokonstriksi, tekanan arteri meningkat, dan denyut jantung cepat sehingga dapat meningkatkan tekanan darah.

Hubungan antara olahraga dengan hipertensi pada lansia diatas 65 tahun yang berobat di puskesmas Simpang Tiga Pekanbaru.

Berdasarkan uji statistik diperoleh nilai $p=$ value $>0,05$, yakni sebesar 0,135 . Hal ini berarti Ho gagal ditolak tidak ada hubungan antara olahraga dengan hipertensi. Hasil penelitian ini sejalan dengan penelitian Rachman (2011) yang menunjukkan bahwa tidak ada hubungan bermakna antara olahraga dengan hipertensi pada lansia.

Namun, hasil kedua penelitian ini bertolak belakang dengan teori yang dikemukakan oleh Smeltzer dan Bare (2002) yaitu salah satu faktor resiko hipertensi yang dapat dirubah (modifiabel) adalah inaktivitas fisik seperti kurang olahraga. Tidak terdapatnya hubungan antara olahraga dengan hipertensi karena olahraga yang dilakukan lansia masih belum sepenuhnya dengan mekanisme yang baik. Pada saat mereka melakukan olahraga, jenis, waktu, intensitas serta frekuensinya kurang tepat atau terlalu lama sehingga tidak sesuai dengan standar kesehatan. Menurut teori yang dikemukakan oleh Fatmah (2010) sebaiknya olahraga dilakukan secara rutin yaitu 3 (tiga) kali dalam seminggu dengan durasi 30 menit.

\section{KESIMPULAN}

1. Umumnya lansia yang berumur $60 \quad-74$ tahun menderita hipertensi berasal dari suku melayu.
2. Umumnya lansia yang berjenis kelamin laki-laki lebih banyak menderita hipertensi dibandingkan lansia perempuan yang menderita hipertensi.

3. Umumnya lansia yang menderita hipertensi mempunyai riwayat keturunan hipertensi.

4. Umumnya lansia yang tidak obesitas lebih banyak menderita hipertensi dibandingkan lansia yang obesitas.

5. Umumnya lansia yang menderita hipertensi lebih banyak mempunyai kebiasaan merokok dibandingkan lansia yang tidak merokok.

6. Umumnya lansia yang menderita hipertensi mengalami stres dibandingkan lansia yang tidak stres.

7. Umumnya lansia yang menderita hipertensi tidak rutin untuk berolahraga dibandingkan lansia yang rutin berolahraga.

8. Ada hubungan antara faktor keturunan dengan hipertensi pada lansia di atas umur 65 tahun yang berobat di puskesmas Simpang Tiga Pekanbaru tahun 2013 dengan hasil $p$ value $=0,008$.

9. Tidak ada hubungan antara faktor jenis kelamin, obesitas, kebiasaan merokok, stres, dan olahraga dengan hipertensi pada lansia yang berobat di puskesmas Simpang Tiga Pekanbaru tahun 2013.

\section{SARAN}

1. Disarankan kepada lansia diatas 65 tahun yang menderita hipertensi untuk melakukan pengontrolan tekanan darah secara rutin dan

2. Disarankan kepada petugas kesehatan untuk melakukan promosi kesehatan atau pencegahan hipertensi terkait lansia

\section{UCAPAN TERIMAKASIH}

Peneliti mengucapkan terimakasih kepada pembimbing 1 dan pembimbing 2 yang telah memberikan bimbingan dalam penyelesaian penelitian ini. Kepada pihak puskesmas Simpang Tiga yang telah memberi izin untuk dilakukan penelitian terkait hipertensi pada lansia yang berada di wilayah simpang Tiga Pekanbaru.

\section{DAFTAR PUSTAKA}

Adila, (2010). Faktor-faktor yang berkonstribusi terhadap kejadian hipertensi esensial pada dewasa tengah di wilayah kerja puskesmas Perhentian Luas. Skripsi tidak dipublikasikan.

Azizah, L.M. (2011). Keperawatan Lanjut Usia. Yogyakarta: Graha Ilmu.

Dinas Kesehatan Kota Pekanbaru Laporan Tahunan Data Kesakitan 2011.

Depkes R.I. (2006). Pharmaceutical care untuk penyakit hipertensi. Diperoleh dari 
http://www.4shared.com/get/115715476/eb9ce9 7e/ HIPERTENSI.html.

Efendi. F., \& Makhfudli. (2009). Keperawatan kesehatan komunitas. Jakarta: Salemba Medika.

Familia, D., \& Dewi, S. (2010). Hidup bahagia dengan hipertensi. Jogjakarta: Aplus Books.

Fatmah. (2010). Gizi lanjut usia. Jakarta: Erlangga.

Lewa, A.F., Pramantara, D.P., \& Rahayujati, B. (2010). Faktor-faktor resiko hipertensi sistolik terisolasi pada lansia. Berita kedokteran masyarakat, 26(4), 173-177.

Lovibond, S.H. \& Lovibond, P.f. (1995). Depression anxiety stress scales (DASS). Diperoleh dari http://www.swim.edu.au/victims/resources/assers ment/affect/DASS42.html.

Notoadmodjo, S. (2007). Kesehatan masyarakat \& seni. Jakarta: Rineka Cipta.

Ode, S.L. (2012). Asuhan keperawatan gerontik. Yogyakarta: Nuhamedika.
Rachman, F. (2011). Berbagai faktor yang berhubungan dengan hipertensi pada lansia. diperoleh http://eprints.undip.ac.id330021Fauzia.pdf

Rusdi., \& Isnawati, N. (2009). Pedoman hidup sehat. Yogyakarta: Power Books.

Sarasaty, (2011). Faktor-faktor yang berhubungan dengan hipertensi pada kelompok lanjut usia di kelurahan sawah baru kecamatan ciputat kota tangerang selatan. Diperoleh dari http://perpus.fkik.uinjkt.ac.id/filedigital/RINAW ANG\%JADI.pdf.

Smeltzer, S.C., \& Bare, B.G. (2002). Buku Ajar Keperawatan Medikal Bedah, Edisi 8 (Endah Pakaryaningsih, Monica Ester, Penerjemah). Jakarta: EGC.

Yenni, (2011). Hubungan dukungan keluarga dengan kejadian stroke pada lansia hipertensi di wilayah kerja puskesmas Bukit Tinggi. Diperoleh dari http://lontar.ui.ac.id/file=digital/20282740/pd 